\title{
Mellom to stoler: møtet med den rusmisbrukende og psykotiske pasient
}

Ved Ingrid M elle

Det blir mer og mer vanlig at personer med psykotiske lidelser også har problemer med rusmidler. Dette øker risikoen for et mer alvorlig forløp av begge lidelsene. Fordi lidelsene vanligvis behandles innenfor to forskjellige behandlingssystemer, er det stor risiko for at pasienter med dobbeltdiagnoser faller "mellom to stoler".

\section{Innledning}

Det blir mer og mer vanlig at personer med psykotiske lidelser også har et rusmisbruk (W eaver et al. 1999). På fagsjargong kalles de gjerne pasienter med "dobbeltdiagnoser". Egentlig er utrykket upresist, også andre pasientgrupper kan ha flere alvorlige lidelser eller "diagnoser" samtidig. Vi kan i klinisk praksis oppleve at én person har både en psykose og et rusmisbruk, en annen en psykose og en alvorlig personlighetsforstyrrelse, en tredje en alvorlig personlighetsforstyrrelse og et rusmisbruk. Enkelte ganger treffer vi personer som har tre alvorlige lidelser, slik som psykose, alvorlig personlighetsforstyrrel se og rusmisbruk. Det er klart at det å ha flere alvorlige lidelser samtidig gjør det vanskeligere å få hjelp, og gjør personen mer utsatt for alvorl ige sosiale komplikasjoner.

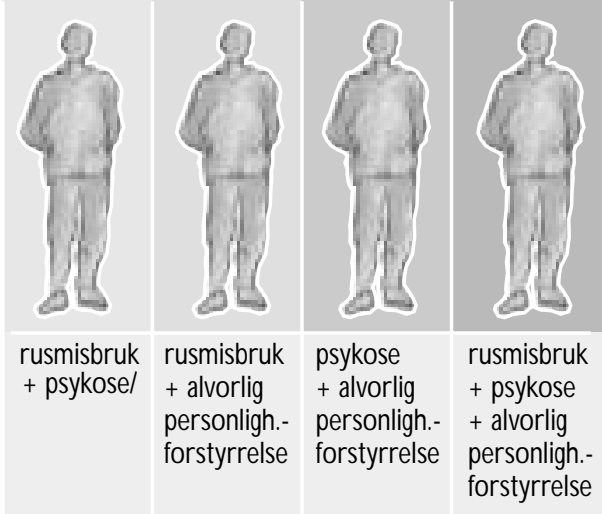

U ndersøkelser anslår at mellom $15 \mathrm{og}$ $60 \%$ av pasienter med alvorlige psykotiske lidelser også har et rusmisbruk. A ndelen med misbruk er høyere hos yngre og i byområder. I en pågående undersøkelse av pasienter med nyoppdagete psykoser i tre opptaksområder i N orge og Danmark har vi funnet at omtrent $50 \%$ har et misbruksproblem allerede ved første gangs kontakt for sin psykotiske lidelse.

\section{Hvorfor er det slik?}

Det kan se ut som om rusproblemer er vanligere hos personer med psykotiske lidelser enn hos andre. M en hva kommer først av "høna og egget"? Øker rusmisbruket risikoen for å bli psykotisk, eller øker psykosen risikoen for rusmisbruk? Per i dag vet vi ikke sikkert om et pågående rusmisbruk øker risikoen for å få en alvorlig psykotisk lidelse. Begge lidelsene starter vanligvis hos ungdom eller unge voksne (A ddington \& A ddington 1998). M ange som utvikler al vorlige psykotiske lidel ser, kan ha uspesifikke psykiske symptomer eller bli økende sosialt tilbaketrukket i flere år før det psykotiske gjennombruddet.

Disse fenomenene kaller vi prodromer "det som løper foran". Det at lidel sene opptrer samtidig, eller at rusmisbruket starter noe før psykosen, kan derfor ikke helt avklare en eventuell årsakssammenheng.

F.eks. kan misbruksmiljøer ha større aksept for sosial tilbaketrekning og problemer med sosial samhandling enn vanlige ungdomsmiljøer, og de kan oppleves som mer sosialt inkluderende av en ungdom i prodromalfasen av psykosen. Forskjellige stoffer kan prøves ut som selvmedisinering for angst, uro eller konsentrasjonsvansker. Samtidig vil misbruket kunne kamuflere utviklingen av psykosen. Problemer med slikt som å komme seg opp om morgenen, eller periodevise angstsymptomer kan da bli betraktet som en følge av misbruket og ikke som psykoserelaterte symptomer. 0 gså det første psykotiske gjennombruddet kan oppfattes som bare en stoffpsykose.

\section{Hva fører det til?}

M ye tyder på at rusmisbruk øker risikoen for tilbakefall av psykose. Pasienter med rusmi sbruk og psykose har også høyere risiko for voldelig atferd. I tillegg har de en økt risiko for suicid (Ruschena et al 1998). Sammenhengen her er kompleks. Risikoen for suicid er $i$ utgangspunktet høy hos pasienter med psykose. Den er særlig høy hos de unge pasientene, og i fasen like før et nytt psykotisk gjennombrudd. Depresjon, enten som del av lidelsen eller som reaksjon på vanskelige livsvilkår, øker også risikoen. En annen risikofaktor er mangel på god behandlingsoppfølging. Vi ser altså at det er mange forhold som spiller inn.
Pasienter med rusmisbruk og psykose er vanskelige å behandle. D e blir oftere akutt innlagt i sykehus og føl ger dårligere opp igangsatt behandling. $M$ en det at pasienten har liten forståelse for behandlingsopplegget har to sider, pasientens og behandlingsapparatets. A skulle forholde seg til to omfattende problemer på en gang vil ofte gi behandleren en følelse av maktesløshet og utilstrekkelighet. $M$ åten vi har organisert hjelpeapparatet på, gjør at vi lett kan kvitte oss med denne ubehagelige følelsen via organisatoriske håndgrep av typen "Ikke mitt bord".

\section{Hva gjør behandlingsapparatet?}

Det er mange likhetstrekk mellom alvorlige psykotiske lidelser og alvorlige misbrukslidelser. Begge har komplekse årsaker, hvor både biologiske og psykologiske faktorer spiller en rolle. De starter oftest hos unge voksne, og har en omfattende innvirkning på omtrent alle livsområder. I studier av sosial fungering er det regelmessig disse to lidelsene som grupper seg sammen helt nederst på skalaen. Begge lidelsene kan også sees på som lidelser som i engelskspråklig litteratur kalles "relapsing-remitting". Det vil si at symptomene går over, men personen har en økt risiko for tilbakefall, sammenliknet med resten av befolkningen. $\mathrm{Vi}$ har ingen behandling som kan fjerne denne risikoen eller sårbarheten. På denne måten er begge langtidslidelser. Fokus i behandlingen er for begge typer lidelser å mestre symptomene, forebygge tilbakefall og håndtere konsekvensene av lidelsen. $M$ en her slutter også likhetstrekkene. I praksis behandles pasientene innenfor relativt atskilte behandlingssystemer; rusomsorgen og psykiatrien. Det er ofte skillelinjer mellom de psykiatriske ungdomsteamene og spesial enhetene for psykotisk ungdom, og store ulikheter i enhetenes behan dlingsfilosofi. M ens psykosepsykiatrien vektlegger et relativt stort ansvar for alliansebyggingen fra behandlerens side og fokuserer på 
omsorg, vil rusbehandleren i større grad fokusere på den enkeltes eget ansvar for å gjøre noe med problemene. H os den ene er man pasient, hos den andre er man klient.

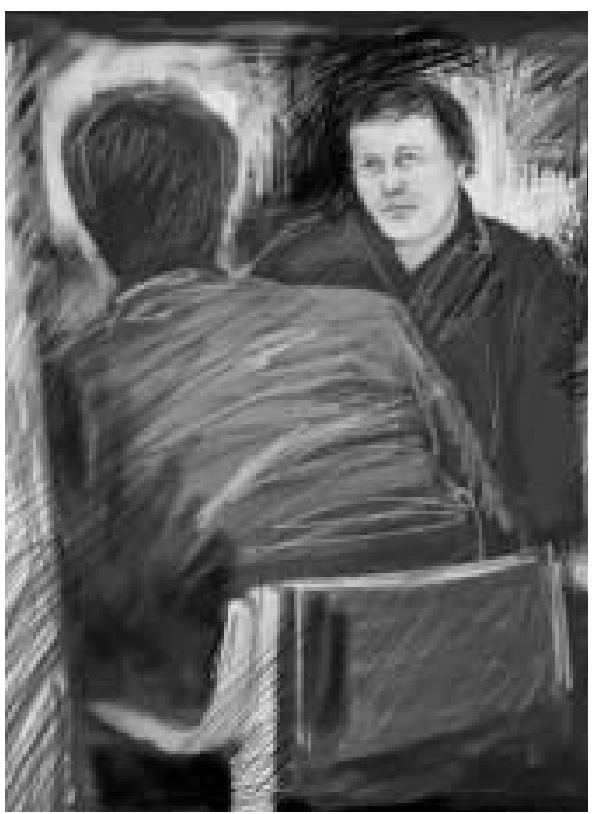

Forståelsesmessig er det to grøfter som det er lett å falle i. Den ene er å forklare hele tilstandsbildet gjennom bare én av lidelsene, den andre er å fokusere på ett isolert symptom av gangen. I praksis gir dette seg de samme utslagene. I beste fall behandler vi lidelsen eller symptomet vi kan noe om, og ser bort fra eller utsetter å forholde oss til de andre problemene. I verste fall definerer vi lidelsen eller symptomene vi ikke kan noe om som det egentlige problemet, og ber pasienten komme tilbake når hun har blitt kvitt dette. De psykiatriske enhetene har en tendens til å havne i den siste groften: R usproblemet blir sett på som noe det må ryddes opp i før personen kan få nødvendig psykiatrisk hjelp. Behandlingsenheter for rusmisbruk har lettere for å havne i den første grøften. Enkelte intensive og konfronterende behandlinger som kan ha effekt på ruslidelser forverrer psykotiske symptomer, men blir benyttet likevel. Enheter som behandler personer med rusmisbruk, har en naturlig skepsis til alle stoffer som påvirker hjernen, og noen vil inkludere antipsykotiske medisiner i denne gruppen og kan dermed motarbeide helt nødven dig behandling.

\section{Konklusjon}

Vi vet at vel halvparten av dem som kommer for sin første behandling for psykose i dag, også har et misbruksproblem. Samtidig rusmisbruk og psykose er nærmest regelen, ikke unntaket. Begge lidelsene er vanlige i de samme al dersgruppene, de er svingende og langvarige. Fra et pragmatisk synspunkt blir det dermed meningløst å diskutere hva som er det "egentlige" problemet som må løses først. Psykotiske pasienter har dessuten store problemer med å forholde seg til komplekse omgivelser. Det er derfor en stor fordel for pasientene om de kan forholde seg til ett behandlingssystem, hvor det mest nødvendige problemet løses først. Dette kan organiseres på forskjellige måter, og forskjellige modeller er under utprøvning. Det er imidlertid viktig at den enkelte behandler både i psykiatrien og i rusomsorgen får økt kompetanse på området, slik at den enkelte pasient ikke lenger faller mellom to stoler.

\section{Aldri \\ Så lenge}

fikk livet aldri tråkke rundt øynene dine at det laget seg stier der.

A ldri streket vinden opp linjer når den øvet seg i skjønnskrift på pannen din.

$\mathrm{H}$ året hang høyt og langt en blank stjernenatt. A Idri skjerpet alderen sølv.

O ss skyver årene videre, jager på. Du hviler på mjuk, eviggrønn ungdom i veikanten og bortenfor verdensrommet.

\section{Kolbein Falkeid}

Fra "En annen sol", 1989

\section{Referanser}

A ddington J \& A ddington D. Effect of substance misuse in early psychosis. British Journal of Psychiatry 1998; 172 (Supplement): 134-6.

Ruschena $D$ et al. Sudden death in psychiatric patients. British Journal of Psychiatry 1998; 172: 331-6.

W eaver $T$ et al. Severe mental illness and substance misuse. British M edical Journal 1999; 318: 137-8.

\section{Anbefalt lesning}

Barrowclough C. Cognitive behavioral intervention for clients with severe mental illness who have a substance misuse problem. Psychiatric

Rehabilitation Skills 2000; 4: 216-233

Ingrid Melle er psykiater med klinisk praksis fra arbeid med psykotiske pasienter. H un arbeider som prosjektkoordinator for prosjektet "Tidlig inter-vensjon ved psykoser" ved Divisjon psykiatri, U llevål sykehus. H un tok sin medisinske doktorgrad på studier av pasienter med psykiske lidelser og har publisert en rekke artikler om dette emnet.

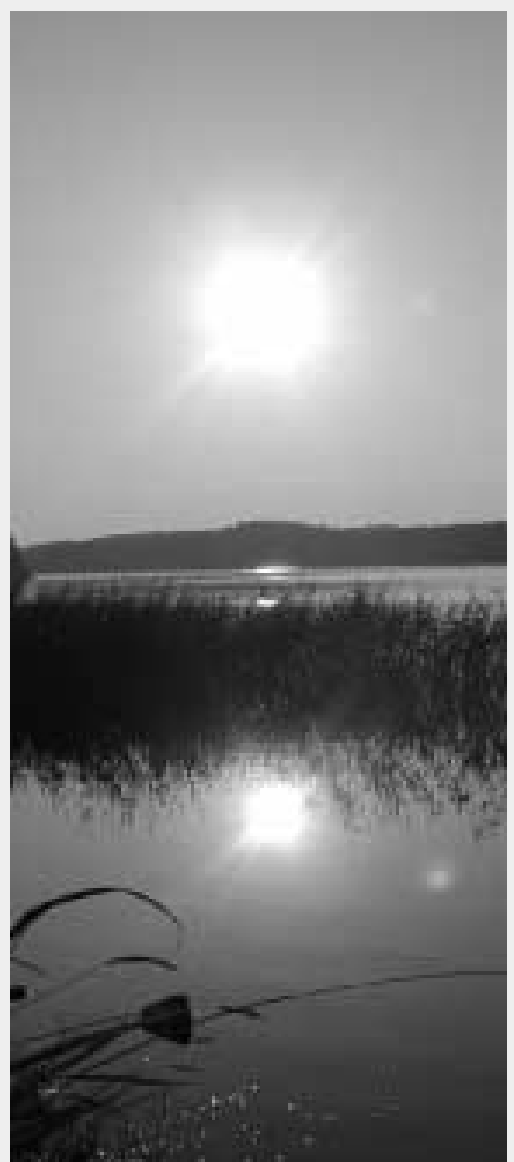

